\title{
Growth and Collapse of a Resource System: an Adaptive Cycle of Change in Public Lands Governance and Forest Management in Alaska
}

\author{
$\underline{\text { Colin M. Beier }}^{1,2}, \underline{\text { Amy Lauren Lovecraft }}^{1}$, and $\underline{\text { F. Stuart Chapin, III }}^{1}$
}

\begin{abstract}
Large-scale government efforts to develop resources for societal benefit have often experienced cycles of growth and decline that leave behind difficult social and ecological legacies. To understand the origins and outcomes of these failures of resource governance, scholars have applied the framework of the adaptive cycle. In this study, we used the adaptive cycle as a diagnostic approach to trace the drivers and dynamics of forest governance surrounding a boom-bust sequence of industrial forest management in one of the largest-scale resource systems in U.S. history: the Tongass National Forest in southeastern Alaska. Our application of the adaptive cycle combined a historical narrative tracing dynamics in political, institutional, and economic subsystems and a longitudinal analysis of an indicator of overall system behavior (timber harvests). We found that federal policies in concert with global market changes drove transformative change in both forest governance (policy making) and forest management (practices), through creation and dissolution of subsidized long-term lease contracts. Evidence of the systemic resilience provided by these leases was found in the analysis of industry responses to market volatility before and after Tongass-specific federal reforms. Although the lease contracts stabilized the Tongass system for a period of time, they fostered a growing degree of rigidity that contributed to a severe industrial collapse and the subsequent emergence of complex social traps. Broader lessons from the Tongass suggest that large-scale changes occurred only when the nested economic and policy cycles were in coherence, and a systemic effort to minimize social and ecological variability ultimately resulted in catastrophic collapse of governance. This collapse resulted in a pervasive and challenging legacy that prevents Tongass reorganization and limits the adaptive capacity of the larger social-ecological system of southeastern Alaska. Although this legacy has inhibited system renewal for two decades, recent trends indicate the emergence of new opportunities for progress toward sustainable governance of the Tongass National Forest.
\end{abstract}

Key Words: adaptive cycle; Alaska; forest management; resource governance; rigidity traps; U.S. National Forests

\section{INTRODUCTION}

Government efforts to stimulate the development of natural resources for public benefit often seek to implement a vision at grand scales that, over time, creates a cycle of dependency that undermines the original social purpose as well as the resource base that was intended to be sustained. In the United States, this has occurred with respect to agriculture (Light et al. 1995), forestry (Repetto 1998, Trosper 2003), fisheries (Francis and Reiger 1995, Pauly et al. 2005), water (Ostrom 1990, Lee 1995), and many other types of resource systems (Holling and Meffe 1996). Similar cycles of dependency have emerged through international aid programs to developing nations that were intended to create self-sufficiency through resource development. Although the goals of these programs are often socially admirable and provide an economic stimulus to initiate changes that would otherwise lack the resources to emerge -i.e., to escape from poverty traps (Carpenter and Brock 2008) - they often result in challenging social traps (Costanza 1987) that can constrain options for future generations. Why have these governance efforts failed so consistently, and what lessons can be learned that would enlighten efforts to address new frontiers of resource governance and public welfare in a rapidly changing world?

${ }^{1}$ University of Alaska-Fairbanks, ${ }^{2}$ SUNY College of Environmental Science and Forestry 
In this article, we analyze the rise, collapse, and aftermath of one of the largest resource governance programs in the history of the United States: industrial timber production in the Tongass National Forest (Tongass) of southeastern Alaska. Although large-scale industrial forestry emerged as a mechanism for stimulating social welfare and economic growth, the Tongass has become one of the most controversial issues of public land management in the United States (Wilkinson 1997). As such, its story has been framed in several ways: as the central theme in the history and purpose of the U.S. Forest Service in Alaska (Rakestraw 1989); as an acute example of political influence, mismanagement, and corruption resulting in environmental degradation (Durbin 1999); as a complex situation governed by entrenched influences and acrimonious personal relationships, as described by a former agency chief (Steen 2004); as a local drama of lost jobs and livelihoods due to "economic vandalism" by environmentalists (Soderberg and DuRette 1988); and as a study of cumulative regulatory complications and policy reforms resulting in conflicted governance and a "deadlock" among institutions and stakeholder groups (Nie 2006).

Although each account yields valuable insights, they present an incomplete and often normative picture of the Tongass case and its broader implications for the regional social-ecological system (SES) of southeastern Alaska; and therefore, provide little guidance on how resource systems might be more effectively governed for long-term sustainability and greater public benefit. In this article, we present the first analysis that examines the links among policy, institutions, economies, and ecosystems that shaped the governance of the Tongass during the 20th century. We apply a resilience lens and use the framework of the adaptive cycle (Holling and Gunderson 2002) as a diagnostic tool to investigate the nested attributes of the Tongass system (Ostrom 2007). Building on a previous group of adaptive-cycle studies of management and governance systems (Gunderson et al. 1995), we (1) developed an adaptive-cycle narrative of the Tongass coupled with a quantitative indicator of system behavior (annual timber harvests), (2) traced the adaptive cycles of policy, institutional, and economic subsystems to identify synergistic feedbacks that drove transformative change at larger scales, and (3) compared adaptivecycle interactions among subsystems to identify sources of resilience and vulnerability.

\section{Objectives and Key Questions}

In this case study, we apply the adaptive cycle as both a theoretical framework and a diagnostic method to reveal the dynamics and interactions of a resource governance and management system nested within a larger SES. We chose the adaptive cycle because the Tongass boom-bust cycle typified the "pathology of resource management" (Holling and Meffe 1996), characterized by a cyclical pattern of dynamics that links ecological (resource) and social (governance) systems in a higher-order coupled system (SES) (Gunderson et al. 1995, Holling et al. 2002b). The adaptive cycle explains the dynamics of a system that is initiated (organization $[\alpha]$ ), mobilizes and develops (growth $[\mathrm{r}]$ ), attains a stable configuration (conservation $[\mathrm{K}]$ ), changes to a different structure (collapse $[\Omega]$ ), and begins the process anew (reorganization $[\alpha]$ ). Our focus is on the coupled cycles of change in governance (through policy and leadership), resource management (through practices and planning), and private industry (through processing and sale of forest products), and their overall impacts on the southeastern Alaska SES. The adaptive-cycle framework supports the systematic identification of key interactions and feedbacks among system components that drove system dynamics, allowing us to address the following questions:

- What factors (ecological, economic, cultural, political) had the greatest overall influence on stability and change in Tongass governance and management?

- What aspects of Tongass governance (via policy) and forest management (via practice) were especially vulnerable to drivers of change?

- How did the system stabilize itself against external perturbation?

- What was the source of this resilience and how was it eventually lost? Was collapse triggered by changes in one or many aspects of the system?

- What aspects of the Tongass system resulted in the social-ecological legacy that currently inhibits renewal toward a more sustainable system of forest governance? 
- How does this legacy inhibit progress? How can this legacy be overcome to facilitate system renewal and restore adaptive capacity?

\section{A Systems Framework}

We define the "Tongass system" as a coupled system of governance (the set of structures and processes by which people make decisions and share power) and management (the set of actions that manipulate a system to achieve desired outcomes) nested within in the larger SES. We recognize three nested subsystems of the Tongass system (Fig. 1): the "institutional subsystem," including the U.S. Forest Service, principally the Tongass administration; the "policy subsystem" that governs Tongass management and land-use decision making; and the "economic subsystem" that defines the structure, capacity, and efficiency of the regional industry and market value of its products. Each subsystem may experience adaptive cycles of change influenced by internal components and drivers of change (e.g., Tongass managers and their preferences, legislation specific to Tongass governance, and economic factors pertaining to local industry) as well as external components and drivers (e.g., national leadership in the Forest Service, federal legislation, and global timber markets) (Fig. 1). Our approach is to explain largerscale SES dynamics by describing the subsystem dynamics, which are more easily observed and can generate transformative feedbacks at larger scales (Walker et al. 2004).

In this article, governance concerns the decisions made regarding the policy goals for the Tongass in the context of a broader vision and purpose for the region of southeastern Alaska, specifically its communities and natural resources. Management is the active implementation of specific practices, such as industrial even-aged forestry, to reach these objectives. Governance emerges primarily from the policy subsystem and management emerges primarily from the institutional subsystem, although the two are functionally coupled.

For this case study, we narrowly define the regional ecosystem with a focus on environmental factors that directly influenced governance and management, and the processes that controlled ecological responses to management practices. These include the condition of the old-growth forest resource, spatial variation in forest productivity, and the remote and rugged geography of the region that shaped the options available for resource development (Fig. 1). We did not address successional dynamics because these primary forests were largely unmodified by human actions when industrial forestry began, and because secondgrowth forests did not reach a harvestable age during the short lifespan of industrial forestry in the region. Hanley et al. (2005) and Beier et al. (2008) address the longer-term ecological implications of clearcut harvesting and even-aged management practices in the temperate rainforests of southeastern Alaska.

\section{APPROACH}

Using this system structure and the adaptive-cycle framework, we developed a historical narrative of the Tongass system that traces a complete loop of the adaptive cycle, beginning with the creation of the Tongass National Forest (1908), passage of key legislation fostering industrial development (1947), boom years during which timber production peaked (1970), collapse of the regional industry (1997), and the contentious stalemate of the present day (2009). In parallel with this narrative, we traced system dynamics using annual timber outputs, a quantitative variable reflecting an emergent property of the Tongass system. Based on this longitudinal analysis (Fig. 2) and a historical timeline of key events in Tongass governance and management (Appendix 1), we described the adaptive cycle of each subsystem, the crosslinkages among adaptive cycles, and events that triggered "tipping points" in the larger SES. In summarizing the narrative, we address our research questions and revisit Holling and Meffe's (1996) "pathology of resource management" concept to draw broader conclusions from the Tongass case.

\section{SYSTEMS NARRATIVE}

\section{Organization Phase $[\alpha]$ 1908-1947}

In the first half of the 20th century, the foundations of the Tongass system emerged during its organization $[\alpha]$ phase - analogous to the "pioneer" stage of forest succession, when several interacting 
Fig. 1. Conceptual diagram of the southeastern Alaska social-ecological system (SES), with an emphasis on the Tongass system, including components and drivers of change of interest in the case study.

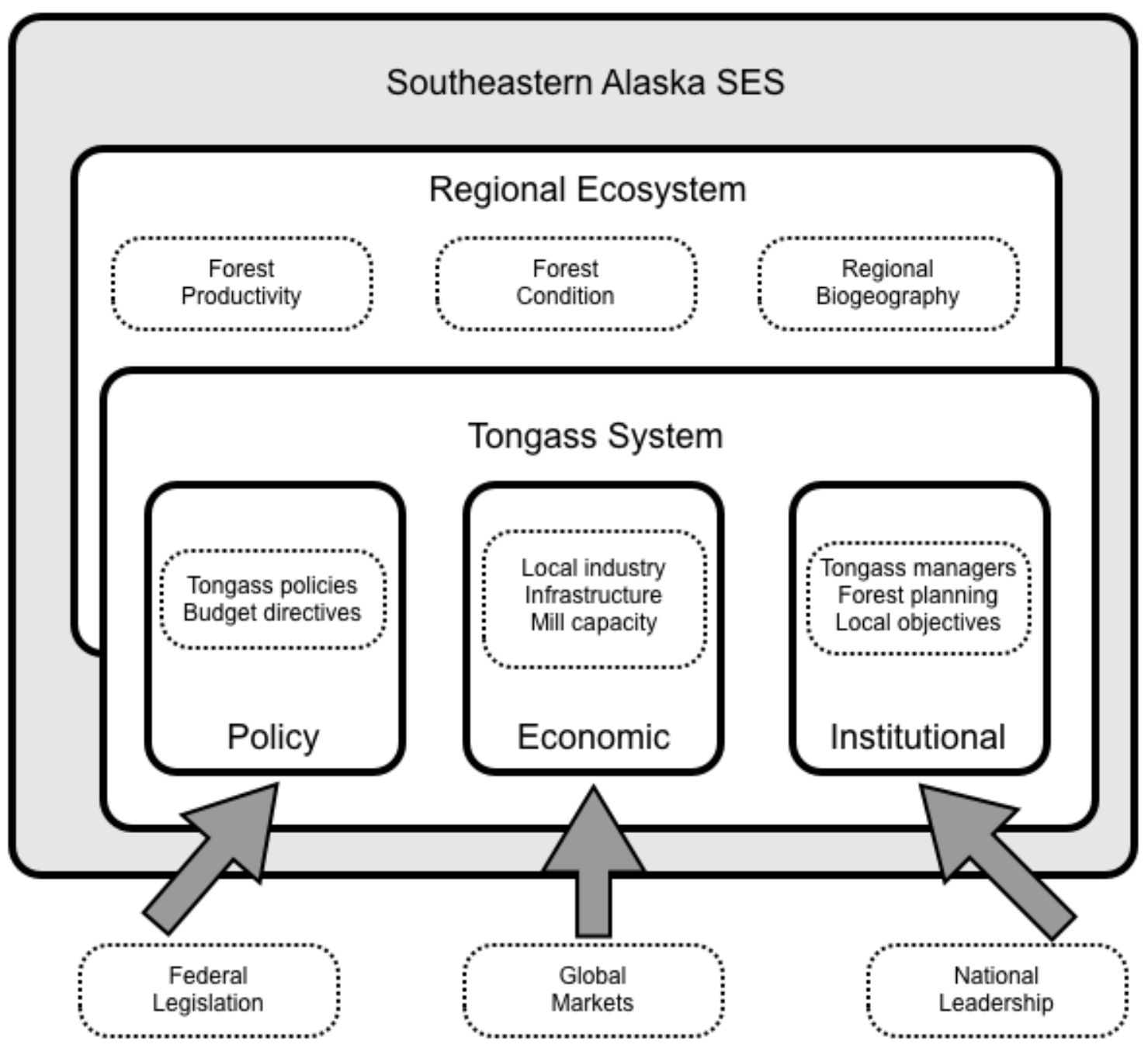

factors dictate the organization of the mature forest in terms of structure, function, and composition. In the Tongass, the arrival of new actors, conditions, and drivers of change interacted to dictate the structure, dynamics, and controls over the future system.

During the 19th century, forests in southeastern Alaska were harvested only for local use, primarily to support fur traders, the salmon industry, and the
Gold Rush. In 1908 - a decade after the U.S. Forest Service was established, four decades after Alaska's purchase from Russia, and coincident with public recognition of Alaska's natural wealth in gold, salmon, and timber - the 6.7 million acre Tongass National Forest was established, and within a year, President Theodore Roosevelt and U.S. Forest Service founder Gifford Pinchot expanded the Tongass by an additional 8.7 million acres to create the largest national forest in the United States. From 
Fig. 2. Longitudinal analysis of annual timber harvest outputs from the Tongass National Forest and subsystem dynamics (see Appendix 2), divided into the four phases of the adaptive cycle: organization, growth, conservation, and collapse.

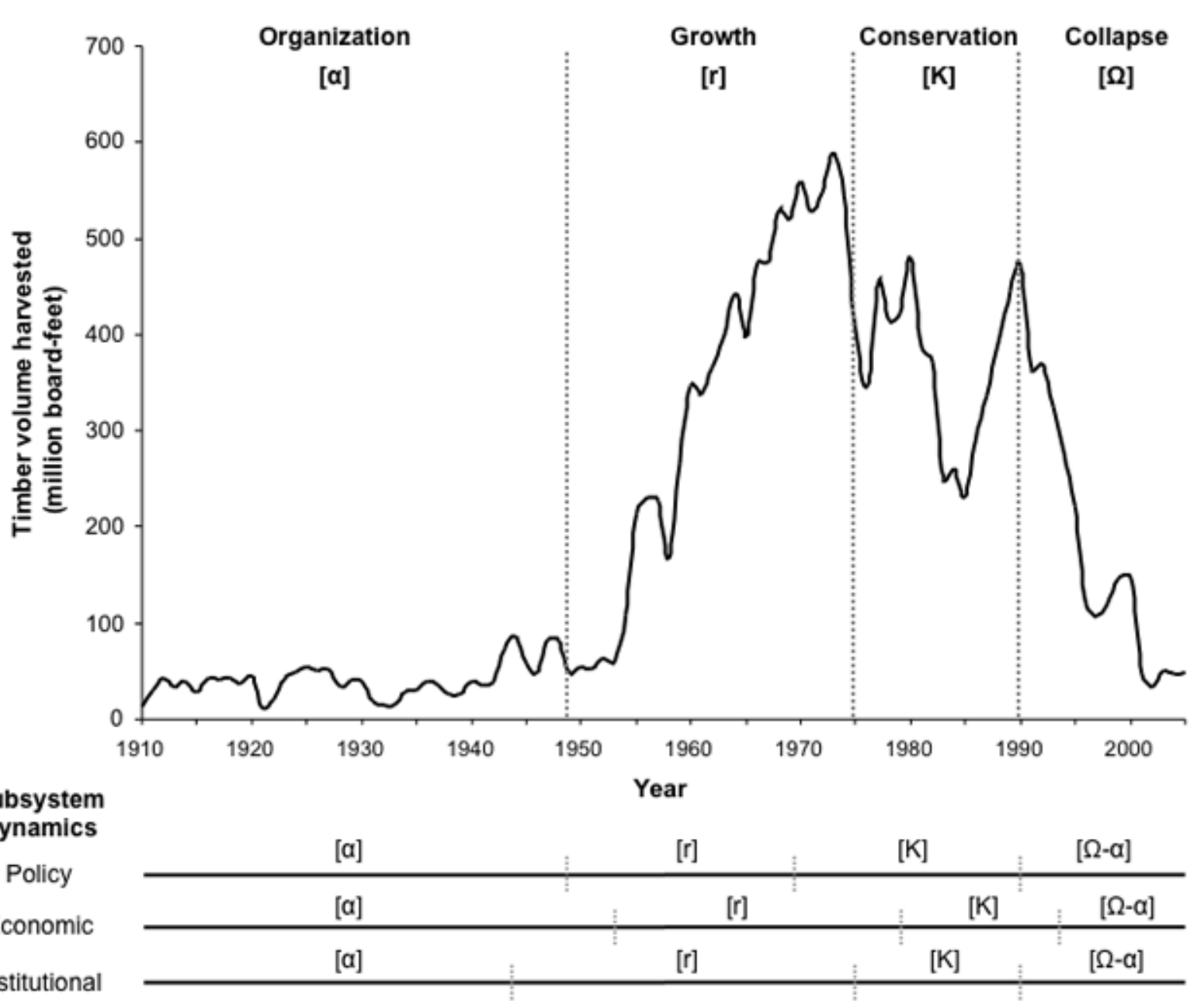

its earliest beginnings, Tongass managers were pioneers of a broad vision to encourage regional population growth and establish a clear U.S. presence in Alaska by developing a strong, selfsufficient economy based on timber production (Rakestraw 1989, Nie 2006). The roots of the Tongass approach - to convert old-growth forests to "more manageable" second-growth stands, while fueling a forest-products industry based on pulp and sawtimber-were evident upon completion of the first federal inventories. In 1909, Tongass officials suggested that pulp production was the best use of old-growth rainforests, that "the chief need is for a planned harvest of the mature timber" (Rakestraw 1989:23), and recommended revision of federal law to allow the sale of National Forest lands for development.

However, this industrial approach required significant private investment to establish a sufficient economy of scale to make Tongass timber profitable. Despite the pursuit of such investments by key figures, including U.S. Forest Service Chief William Greeley in the 1920s and Alaska Regional Forester Frank Heintzleman throughout the 1930s and 1940s, these efforts were thwarted by economic 
constraints, including poor regional infrastructure, distance from markets, and the Great Depression.

World War II and its aftermath provided the catalyst to implement industrial forestry in the Tongass, because American wartime demand for airplane lumber exceeded supplies in Oregon and Washington, which had been depleted during World War I. To capture this opportunity, Heintzleman sought the advice of timber-industry executives in presenting his case for what became the Alaska Spruce Log Program (ASLP). Created as an agency in 1942, ASLP supplied mills in the continental United States with high-grade Sitka spruce logs from the Tongass. At the time, Tongass logging occurred primarily by hand-felling the best trees in accessible sites, such as beach fringes and river bottoms. However, the collective opinion of Tongass managers, many of whom were professionally trained foresters, was that clearcutting was a far superior method (Rakestraw 1989). Taylor's (1935) Ecology article provided scientific justification for the change from high grading to clearcutting in the Alaskan rainforest. With this justification, Tongass managers shifted the silvicultural prescription to clearcutting and sought to demonstrate the economic viability of harvesting the low-grade timber that comprised the majority of the Tongass timber base.

In the 18 months of ASLP operation, the program exported 38.5 million board feet (MBF) of highgrade spruce to continental U.S. mills, and transferred $46 \mathrm{MBF}$ of lower (utility) grade material to local Alaska mills. The ASLP-legislated target was $100 \mathrm{MBF} /$ year of high-grade Sitka spruce, with no mention of low-grade materials whatsoever. Although short lived, the wartime program demonstrated the commercial viability of both sawtimber and utility-grade materials from the Tongass. It also forged strong relationships among Tongass officials, national policy makers, and timber-industry representatives (Rakestraw 1989).

In summary, the organization $[\alpha]$ phase consisted of a series of events that initiated adaptive cycles simultaneously in the institutional, policy, and economic subsystems. These adaptive cycles in the subsystems defined the future configuration of the Tongass system and prepared it for transformation (Appendix 2). Key actors in these subsystems worked together to shape a common vision of industrial forestry in Alaska(i.e., built the horizontal links among subsystems), which they viewed as both the best path to economic growth and selfsufficiency and the best practice for using and managing the region's abundant forest resources.

\section{Growth Phase [r] 1947-1975}

The passage of the Tongass Timber Act (TTA) in 1947 was a landmark event in forest governance that moved the Tongass system into the growth $[\mathrm{r}]$ phase. With the TTA, Tongass officials applied a federally mandated blueprint to mobilize the resources and expertise required to make industrial forestry a reality in Alaska - analogous to the rapid biomass accumulation and altered competitive balance among species in an early successional forest. In the Tongass, this involved development of a trained workforce and infrastructure; long-term timber leases that altered the relationship between forest managers and forest users; and increased production of forest products (Fig. 2). By authorizing long-term guaranteed contracts, favorable scaling and pricing rules, and several other subsidies, the TTA provided the impetus needed to overcome economic thresholds and transform to a new state of industrial forestry.

The provisions of the TTA were framed by legislators, Tongass officials, and timber-industry executives. The latter two groups of actors had negotiated terms of lease contracts before the legislation's passage (Rakestraw 1989). Other interests, including other federal agencies with stakes in Alaska land management, were summarily excluded from negotiations, and the bill received little debate in Congress. The preparation and passage of the TTA galvanized the close links among agency, legislative, and private-industry actors (Rakestraw 1989, Nie 2006), forming a "policy monopoly" (Baumgartner and Jones 1993, Kingdon 1995, True et al. 1999) of the Tongass system, which achieved unprecedented measures to foster industrial-scale forestry, including long-term leases that guaranteed non-competitive access to millions of acres of publicly owned forest land. Lease holders were required to operate pulp mills in the region and, in return, received low-interest loans, a favorable log-scaling system, and refunds of road-building costs (Soderberg and DuRette 1988). Harvest units in leases were planned largely by company foresters and then released to lease holders on demand (without open bidding) by the Tongass. The U.S. Forest Service planning process at this time was relatively unfettered by legislative 
complications, public participation, or judicial decisions (Nie 2006). As a result, there was a low degree of transparency and a high degree of internal control in the execution of the long-term timber contracts; such traits are characteristic of industries operating on public resources through a policy monopoly (Repetto 1988).

Early in this period, the Tongass system mobilized rapidly in the direction prescribed and supported by its policy monopoly. Immediately after the TTA, the U.S. Forest Service and the newly formed Ketchikan Pulp Company (KPC) agreed to preliminary terms of a lease contract. The KPC contract was finalized in 1951 and guaranteed over 8.5 billion board feet of timber over 50 years, subject to 5-year reviews by the U.S. Forest Service; the KPC contract set aside nearly one-fifth of the Tongass for exclusive bidding rights (Soderberg and DuRette 1988). In 1953, the Japanese-owned Alaska Pulp Development Co. was incorporated in the United States and signed a 50-year, 4.5 billion board foot contract requiring construction of a large sawmill and pulp mill in Sitka. By 1959, the Alaska Pulp Company (APC) was in operation in Sitka. Another long-term contract with the Pacific Northwest Timber Co. was finalized with the construction of large sawmill in Wrangell. Other lease offerings included large tracts in some of the most biologically rich areas of the Tongass, e.g., one lease included nearly $90 \%$ of productive forests on Admiralty Island, which today exists as a keystone reserve of regional biodiversity (Beier 2008).

Within 5 years of passage of the TTA, roughly 14 billion board feet of Tongass timber was under contract to lease holders. In 1953, Regional Forester Heintzleman retired from the U.S. Forest Service and was appointed Territorial Governor of Alaska, where he continued vigorous pursuit of progressively larger timber leases in the region (Rakestraw 1989). The three existing lease contracts produced over $90 \%$ of Tongass timber harvested during the 1960s and 1970s. In the early 1970s, the system's growth phase reached several milestones: maximum annual harvest from the Tongass (560 MBF), maximum Alaskan share of U.S. timber exports to Japan (42\%), and the small town of Ketchikan became the third-largest producer of cellulose pulp in the world.

During this period, a series of legislative and judicial decisions (Appendix 3), beginning in 1960 with the
Multiple Use Sustained Yield Act(MUSYA), began to erode the discretional authority of the U.S. Forest Service (LeMaster 1984). These "perturbations" to the Tongass policy subsystem were largely driven by the growing influence of the U.S. environmental movement. With the exception of one major lawsuit (Sierra Club v Hardin), these events were not specific to the Tongass and did not significantly influence system behavior, based on harvest trends (Fig. 2). However, these events did begin to challenge the Tongass policy monopoly and its control over forest governance by establishing new rules and venues for debate and decision making. For this reason, these events provide a window into how the Tongass system was stabilized, or conserved, in the face of change-these interactions are the focus of the following section.

In summary, during the growth [r] phase, Tongass timber outputs grew rapidly and stabilized at a harvest level roughly 20 times greater than during the organization $[\alpha]$ phase (Fig. 2). This transformation in the Tongass system resulted from a solidification of the links among the institutional, policy, and economic subsystems, creating a rigid system that had minimal transparency or links to other processes such as the environmental lobby or small-scale logging companies that had interests in Tongass governance. The mills in Ketchikan, Sitka, and Wrangell prospered, and the regional industry supported an estimated 3500 local jobs and numerous local schools, which benefited from direct transfers of timber-based revenues (Allen et al. 1998). At the beginning of the [r] phase, legislation created positive feedbacks in the policy subsystem that triggered implementation of the Tongass system; and toward its conclusion, legislation created negative feedbacks that increased the rigidity of internal links among all subsystems of the Tongass. During this period, the economic subsystem was driven largely by positive feedbacks fostering continued growth in forestproducts manufacturing (Appendix 2), which peaked in 1970. Because of the tight links among the three subsystems, the positive feedbacks in the policy and economic subsystems drove the growth of the Tongass system.

\section{Conservation phase $[K]$ 1975-1990}

Before 1975, the Tongass system and its policy monopoly remained largely unfettered by changes in public opinion and federal policy associated with 
the environmental movement. In 1975, for the first time, a federal court ruled against the practice of clearcut logging in the Tongass. This event moved the Tongass system into a conservation $[\mathrm{K}]$ phase - a state analogous to the "climax" stage of a mature forest when the dominant canopy trees strongly influence endogenous conditions and the system is largely resilient to disturbance (Holling and Gunderson 2002). During this phase, the Tongass system faced external, converging drivers of change in public policy (Nie 2006), institutional governance (LeMaster 1984), and global markets (Crone 2004). The interactions of these drivers with components of the Tongass system revealed the mechanisms providing stability and resilience, as well as incipient vulnerabilities. The conservation phase is aptly named in two senses: it was a period of growing influence of environmental (conservation) advocates in Tongass governance; and it was a period in which the Tongass system was stabilized (or conserved) against directional and mostly external drivers of change. The latter meaningmaintenance of the system status quo-is our focus.

In lawsuits against the U.S. Forest Service in Montana and West Virginia, federal courts ruled that clearcutting in National Forests was in violation of the intent and language of the Organic Act of 1898 (Nie 2006). Immediately afterward, environmentalists filed suit (Zieske $v$ Butz) to prevent further Tongass clearcut logging by KPC and won an initial victory. This ruling was the first direct challenge to the legality of an existing Tongass long-term contract. By contrast, the Sierra Club v. Hardin action (1965-1971) sought to prevent a pending contract by opposing its associated pulp mill on environmental grounds. The Zieske v Butz decision set a powerful, albeit brief precedent against industrial-scale logging in the Tongass; if broadly applied, the decision would have forced the U.S. Forest Service to default on the timber contracts upon which the regional industry depended. The Tongass decision, and those that preceded it, led to a stalemate that required immediate intervention by the U.S. Congress.

The National Forest Management Act (NFMA), drafted largely to allow National Forest timber operations to resume, prescribed broad reforms to the U.S. Forest Service planning process. Adding further to complications created by earlier legislation, the NFMA required each National Forest to complete a comprehensive management plan using an interdisciplinary approach with greater opportunities for public participation.
Moreover, the NFMA strongly reiterated the multiple-use concept (of MUSYA), but neither provided specific guidelines for its application, nor reduced the agency's discretion in achieving the multiple-use objective. As a result, legislators left NFMA's intent open to debate and effectively transferred the venue of that debate to federal courts, in turn fostering the legal "obstructionism" that has become the principal source of paralysis in U.S Forest Service planning (Nie 2006). With growing opposition to the long-term leases, the Tongass planning process became one of the most contentious in the nation (Malmsheimer et al. 2004).

Tongass governance was further complicated by the Alaska National Interest Lands Conservation Act (ANILCA) of 1981, which reserved nearly onethird of Tongass lands as protected areas. As a result, the ANILCA effectively reduced the operable Tongass timber base (productive forest land), also by roughly one-third (Beier 2008). The Tongass was one of the most contentious issues in the ANILCA debate (Cahn 1982) because of vehement opposition by the Tongass policy monopoly and local stakeholder groups who viewed land withdrawals as a direct threat to regional economic welfare (Nelson 2004). In exchange for difficult compromises on wilderness designation in the Tongass, a number of provisions supporting the regional industry and assuring subsidies to lease holders were included in the ANILCA (Beier 2008). The most significant Tongass-related provision negotiated into the bill by Senator Ted Stevens authorized at least $\$ 40$ million annually to support the timber-sale program. With this guaranteed funding, the Tongass was instructed to supply the regional industry 4.5 billion board feet of timber volume per decade. This provision had the effect of formally redefining the allowable (maximum) sale quantity prescribed in the 1979 Forest Plan as the target harvest quantity. Tongass managers interpreted this as a mandate to harvest $450 \mathrm{MBF}$ each year regardless of market demand (Nie 2006), in turn creating an additional source of rigidity in the institutional subsystem of the Tongass. The funding also supported low-interest loans for lease holders, research for improvement of forest yields and processing efficiency, and new markets for Tongass forest products. The ANILCA also exempted the Tongass from federal guidelines requiring removal of non-commercial-grade forests from the operable timber base. In total, these provisions had the effect of reaffirming timber production as the "best use" of all non-reserved Tongass lands. 
During this period, increased volatility in timber export markets, and the industry response to these fluctuations, signaled the shift of the economic subsystem into the [K] phase (Appendix 2). In 1979, export markets for Tongass pulp products experienced a dramatic decline that lasted throughout much of the 1980s, due mostly to shifts in global demand and increased competition (Rakestraw 1989). Tongass harvests declined closely in parallel with market fluctuations (Fig. 2), suggesting that much of the regional industry was operating at or near the margin, despite the considerable subsidies received by the long-term lease holders. Meanwhile, increased competition and the growing disparity between Alaskan mills and their competitors, in terms of technology and efficiency, posed major challenges to the regional industry (Crone 2004).

In summary, during the conservation $[\mathrm{K}]$ phase, the Tongass system proved resilient to multiple perturbations from legal challenges and new legislation that had either a national focus (NFMA, Endangered Species Act (ESA), National Environmental Policy Act (NEPA)) or an Alaskawide focus (ANILCA), as well as market fluctuations driven by global demand and increased competition. Although federal environmental legislation and subsequent judicial decisions began to erode the primacy of U.S. Forest Service discretion in governance, the Tongass policy monopoly was able to minimize the impact of these changes; and in response to its most direct threat (to date), was able to safeguard its authority in the ANILCA debate (Beier 2008). Hence the policy subsystem was in a $[\mathrm{K}]$ phase because the policy monopoly remained resilient in the face of rapidly strengthening and expanding drivers of change (Appendix 2). Resilience in the policy subsystem prevented these perturbations from strongly destabilizing either the institutional or the economic subsystems, thus stabilizing the entire Tongass system. However, this stability arose entirely through the addition of rigidity to existing links among subsystems, setting the stage for collapse of the entire Tongass system, as we describe below.

\section{Collapse Phase $[\Omega]$ 1990-2008}

Passage of the Tongass Timber Reform Act (TTRA) initiated the collapse [ $\Omega]$ phase of Tongass management-analogous to the release stage typically initiated by a stand-replacing event, such as a fire or disease outbreak, that exceeds the resilience of the mature forest. Likewise, the "mature" Tongass system became rigid and maladaptive in response to a confluence of events that fostered simultaneous collapse dynamics in the policy and economic subsystems. Within 5 years of the passage of the TTRA, Tongass timber production declined by roughly $85 \%$ and stabilized at an output level equivalent to the pre-industrial production level (Fig. 1).

In a 1983 lawsuit, Reid Bros. Logging v Ketchikan Pulp Co., the plaintiffs claimed that KPC unfairly forced smaller operators out of the industry. The court ruled that KPC had engaged in illegal conspiracy and anti-competitive practices, and in subsequent lawsuits, ruled that KPC and APC had colluded to marginalize the smaller timber companies (Durbin 1999). These rulings did not immediately affect the long-term leases, but certainly contributed to the legislative rebuke of the lease structures codified several years later in the TTRA (Nie 2006).

In a strong rebuke of the legitimacy of the long-term leases, the TTRA essentially dismantled the Tongass policy monopoly, which in turn drove the policy subsystem to collapse. First and foremost, the TTRA repealed the minimum annual harvest mandate and associated subsidies that were won by Tongass advocates in the ANILCA debate and instead instructed managers to "provide for the multiple use and sustained yield of all renewable forest resources," to "seek to provide a supply of timber" according to market demand, and to "promote fair competition" in the regional industry [emphasis added]. The law modified the lease contracts by eliminating bidding preferences, purchaser road credits, and pricing advantages given to lease holders. The TTRA also created Tongass-wide stream buffers to protect local fisheries, which removed some of most productive (and valuable) remaining Tongass stands from potential harvest (Nie 2006). As interpreted by the 9th U.S. Circuit Court of Appeals, the TTRA instructed that Tongass management was to be guided by "not an inflexible harvest level, but a balancing of the market, the law, and other uses, including preservation" [emphasis added].

In the economic subsystem, investors and industry executives viewed the TTRA as a sign that Tongassbased operations would no longer be predictable or profitable (Nie 2006). A number of other indicators, 
mostly related to market volatility and aging mill infrastructure, also pointed to industry collapse. First, the APC contract depended on the sustained levels of high Japanese demand for Alaskan sawtimber and cellulose pulp, even after post-war reconstruction had been completed. By 1985, due to a decline in pulp markets, the Tongass share of U.S. timber exports to Japan dropped to its lowest point $(6 \%)$ since APC began operations in Sitka. Second, by the 1980s, most mill facilities in Alaska lagged far behind regional and global competitors in terms of efficiency and technology. Yet because of the age and capital amortization of most mills in the region, decisions about both production levels and mill improvements were largely driven by short-term profitability. Coupled with the high operating costs in southeastern Alaska, poor markets triggered sporadic mill closures and reopenings throughout the 1980s and 1990s (Morse 2000). Between 1984 and 1987, all of the major mills in the region-except those owned by KPC and APC - closed for at least a 3-year period, and two of these mills never reopened (Brackley et al. 2006). This volatile economic environment, in concert with growing political uncertainty, strongly discouraged further investment in mill operations or improvements.

Soon after the TTRA, Alaskan export markets experienced another cyclical downturn similar to that of the 1980s, although of lesser magnitude in terms of price deflation (Crone 2004). This time, however, lease holders decided to close the major pulp mills in Sitka (in 1994) and Ketchikan (in 1997). These mill closures violated the terms of the lease contracts, which were subsequently terminated by the U.S. Forest Service, prompting a round of lawsuits by the lease holders; APC lost their case, and KPC settled for $\$ 140$ million.

In the institutional subsystem, the TTRA ushered in an era in which Tongass decision making effectively shifted to judicial and political venues outside of the agency (Nie 2006). A recent study estimated that from 1997-2003, 88\% of NEPA-required environmental impact statement (EIS) decisions were appealed on the Tongass; of these, nearly all concerned timber sales, road permits, and other related development activities (U.S. Department of Agriculture (USDA) Forest Service 2004). The accumulation of several decades of environmental policies and planning statutes concerning the U.S. Forest Service fostered an environment where "the threat of judicial review, injunction, remand, and the like cast a very long shadow on agency decision making" (Nie 2006). Two events immediately following the TTRA created further uncertainty in the Tongass administration: first, a 1991 moratorium on National Forest logging in Oregon and Washington was enacted in response to the northern spotted-owl (Strix occidentalis caurina) controversy and the ESA (Trosper 2003); second, the election of President Clinton (1992) caused major political shifts in the U.S. Forest Service, symbolized most clearly by the appointment of wildlife biologist Jack Ward Thomas as agency chief, the first non-forester in agency history to hold that position (Steen 2004).

During this turbulent period, the Forest Service was in the process of revising the 1979 Tongass Forest Plan, as required by NFMA. Because the TTRA was enacted 3 years into the Forest Plan revision process, the law required Tongass officials to "go back to the drawing board," which eventually resulted in a decade-long, \$13 million planning effort (Nie 2006). In many ways, this planning process and its priorities suggested a new direction for Tongass governance, as the new Forest Plan and the process of its development were starkly different from its predecessor. The 1997 Tongass Land Management Plan (TLMP) incorporated the principles of ecosystem management, species conservation, and old-growth forest reserves, and designated roughly $36 \%$ of the Tongass in a land-use category of "Natural Setting," where minimal timber harvesting and road construction is allowed. In doing so, the 1997 TLMP reduced the operable Tongass timber base and maximum allowable annual sale quantity by nearly half. Including the reserves created by the ANILCA in 1980, the 1997 TLMP left $28 \%$ of the Tongass land base for timber production. By contrast, roughly $95 \%$ of productive forest lands were scheduled for harvest when Congress passed the Tongass Timber Act in 1947. Clearly, the Tongass had reorganized its institutional priorities, as forced primarily by "new" factors, namely decades of policy reforms and political shifts related to public opinion against clearcutting (Bliss 2000).

Despite new factors shaping the Tongass system, this period has been consistently influenced by powerful remnants of the erstwhile policy monopoly. Although the Alaska congressional delegation unsuccessfully obstructed the passage of the TTRA and strongly opposed the conservation directives of the 1997 TLMP, they effectively used legislative committee positions and seniority to 
exert their influence through budget "riders"additions to bills unrelated to their intent - and other instruments, some of which have been adversarial in nature. For example, in exchange for allowing the TLMP planning process to proceed with additional conservation areas and reduced emphasis on timber operations, Senator Stevens appropriated $\$ 110$ million of "Tongass Disaster Relief Funds" from the federal budget, yielding individual payouts ranging from $\$ 30000$ to $\$ 100000$ per lost job (Whitney 1996). Senator Stevens and the Alaska delegation also used, with varying levels of success, numerous riders to influence Tongass governance, including: a separate annual payment of approximately $\$ 30$ million in "relief funds" to the city of Ketchikan; a 1995 provision that would have strictly limited the discretion of Tongass managers to set new logging limits and conduct NEPArequired environmental research; and a 1998 provision that would have instructed the Tongass to prepare exactly $253 \mathrm{MBF}$ for sale the following year. This last provision, which was removed from the budget before passage, outlined specific legal and fiscal consequences if Tongass managers did not fully comply. As of 2008, these "appropriation politics" have remained the dominant way the Tongass is governed by the Congress (Nie 2006).

In summary, the collapse $[\Omega]$ phase was initiated by dramatic and Tongass-focused policy changes (TTRA) that effectively dismantled the Tongass policy monopoly and thus irreversibly transformed the policy subsystem. Closure of the pulp mills in Sitka and Ketchikan, triggered largely by fiscal concerns arising from both loss of lease subsidies and market volatility, forced action in the institutional subsystem to terminate the long-term lease contracts. As the glue that held the entire governance system together-i.e., coupling the institutional, economic, and policy subsytems of the Tongass into a rigid configuration-the dissolution of lease contracts had catastrophic consequences. Rigidity in the system, created initially to promote growth but increased over time as a mechanism to resist external changes, precluded any efforts to adapt or transform. Since collapse, Tongass governance has been largely incapable of reorganization.

\section{DISCUSSION}

The preceding narrative suggests the importance of changes in federal policy and larger-scale economic factors as the key drivers of adaptive-cycle dynamics in Tongass governance. Policy mobilized much of the initial growth, provided much of the stability during the conservation phase, and served to destabilize - at first incrementally and then rather suddenly - the industrial forestry regime of the Tongass. The changing economic context dictated the timing of policy implementation (growth phase) and eroded the resilience of the Tongass system during its collapse. We found that, in both the initiation and collapse of the Tongass system, transformative change occurred only when the adaptive cycles of two or more subsystems were in coherence-in other words, when some synergy existed in economic, political, and institutional components. Our observation that policy drivers resulted in brief, dramatic changes (or "lurches") interspersed with long periods of relative stability, is consistent with punctuated equilibrium theories of policy making (True et al. 1999). As observed in other forest-governance systems (Baskerville 1995), this suggests that non-linear shifts in policy can drive similar dynamics in larger-scale governance systems involving ecological, economic, and institutional components and controls (Holling et al. 2002b).

We can trace the importance of the policy monopoly throughout the Tongass adaptive cycle. In the "foreloop" of growth $[\mathrm{r}]$ and conservation $[\mathrm{K}]$, the policy monopoly fostered change by creating the long-term leases and subsequently provided stability to the system against external perturbations. Growth was fostered by policies that created incentives for local investment to capture the market opportunities emerging from post-World War II reconstruction. These horizontal links between the policy and economic subsystems fostered resilience. Stability was also fostered in the institutional subsystem by maintaining exclusive control over venues of decision making and planning, by ensuring lease holder subsidies, and by influencing policy making at various scales as it pertained to the Tongass. Overall, by maintaining the legitimacy of the longterm leases, the policy monopoly conserved the entire system's stability. Over time, however, this monopoly was eroded as the feedbacks of environmental and regulatory reforms accumulated in both the institutional and policy subsystems. These reforms reflected broader changes in public 
opinion (Bliss 2000) associated with the environmental movement at scales larger than the Tongass and were specifically provoked by management outcomes and legal actions in other National Forests (Trosper 2003). As these crossscale feedbacks (panarchy) drove collapse in the policy subsystem, the Tongass system lost its resilience to market-oriented perturbations and experienced a precipitous decline in outputinitiating dynamics of collapse $[\Omega]$ and providing opportunities for potential reorganization $[\alpha]$ that have not yet been realized.

Evidence of this policy-supported resilience can be found by comparing system dynamics (annual harvest outputs) during two periods of price depression in Alaskan export markets: (1) during the 1980s while the long-term lease subsidies were in place and (2) during the 1990s after the TTRA eliminated lease subsidies. During the first severe price depression faced by the Tongass-based industry, although the long-term leases and subsidies were considered safe, market volatility resulted in similar fluctuations in harvest output. When market prices recovered and stabilized, harvests rebounded to previous levels (Fig. 2). In other words, when the policy subsystem was resilient, it afforded resilience to the economic subsystem by assuring investor confidence in the long-term leases and future profit potential (Nie 2006). In contrast, when a second, but less severe, market downturn occurred in the early 1990s (Crone 2004), the entire system collapsed, triggered by closure of the regional pulp mills and the subsequent termination of both lease contracts. We suggest the principal difference was the state of the policy subsystem, which had entered a collapse $[\Omega]$ phase (upon passage of the TTRA) before the second market downturn. Therefore, by reducing investor confidence in a stable timber supply from the Tongass (Nie 2006) in addition to eliminating subsidies, the TTRA destabilized the economic subsystem, making it much less resilient to market volatility.

Lastly, our case study illustrated the importance of scale mismatches and cross-scale interactions in the SES. Because of a relatively short observation period, the apparent lack of negative impacts of even-aged management practices in Alaska led managers to falsely conclude that ecological responses to logging practices were benign, if not favorable. In fact, the short-term feedbacks at the local scale were almost entirely positive, both in terms of societal benefits and reinforcing scientific assumptions about forest responses to clearcutting (Rakestraw 1989). Today, however, recognition of the lagged ecological costs of forest harvest in Alaska (Beier et al. 2008) has prompted urgent efforts to sustain subsistence and commercial resources while managing second-growth forests. Of course, this mismatch in temporal scales (i.e., ecological processes vs. human observation) was apparent in the longer-term outcomes from similar forest management in the U.S. Pacific Northwest. Environmental advocates who perceived the degradation of these National Forests resulting from similar industrial practices (Trosper 2003) feared a similar fate for the Tongass in Alaska (Durbin 1999). Their dramatic influence on National Forest governance in the late 20th century acted across scales to end industrial logging in the Tongass. This suggests that ecological feedbacks from other regions, through processes fostered by a democratic society, act to drive transformative change in governance.

\section{Holling's Pathology and the Tongass Rigidity Trap}

In many ways the Tongass case epitomizes the "pathology of resource management" described by Holling et al. (2002a: 6):

New policies and development usually succeed initially, but they lead to agencies that gradually become rigid and myopic, economic sectors that become slavishly dependent...and a public that loses trust in governance.

For the Tongass, an initial period of rapid growth gave way to a period in which Holling's pathology became obvious. Forest managers became bound to the rigid requirements of the long-term contracts regardless of dramatic changes in their political and economic landscape. As this landscape shifted, Tongass governance remained rigidly focused on executing lease contracts and sustaining the regional industry. The fate of the industry and its dependent communities hinged on lease holder subsidies that sought to ensure the local manufacture of forest products would continue in conjunction with favorable export markets. In addition to employment and infrastructure development provided by the forest-products economy, many remote southeastern Alaska communities relied 
heavily on U.S. Forest Service timber receipts for public-school funding (Allen et al. 1998). Not unique to the Tongass, this "slavish dependence" of agency, economy, and community has been a characteristic outcome of U.S. National Forest timber programs (Repetto 1988), especially in the Pacific Northwest (Trosper 2003).

The Tongass adaptive cycle illustrates how "command-and-control" management (Holling and Meffe 1996)—the attempt to control system variability, and the assumption that outcomes would be static and predictable-may emerge in the organizing principles of a resource system, be successful for a period of time, but eventually yield to catastrophic failure. Overall, this approach created intrinsic vulnerabilities that were largely masked during the boom years of Tongass timber, but have left a multifaceted legacy that includes the current political stalemate (Nie 2006), a less competitive regional industry (Crone 2004, Brackley et al. 2006), and concerns about capacity of managed forest watersheds to sustain local production of resources-including timberessential for subsistence and commercial economies (Beier et al. 2008). Each of these outcomes points to the existence of "rigidity traps" preventing reorganization of the Tongass system to address new challenges and opportunities (Carpenter and Brock 2008).

First and foremost, the loss of trust in governance is probably the only shared perspective among the environmental advocates, industry representatives, legislators, and local residents who engage in continuous conflict over the Tongass. Although the Tongass situation is not unique in the National Forest system, its importance as an icon of the global environmental movement (Durbin 1999) has raised the stakes considerably. In the current state, Tongass managers are pitted between environmental advocacy groups (via litigation and appeals) and pro-timber legislators and executive officials (via budgets and national leadership). This situation acts to maintain day-to-day Tongass decision making in a highly stable but inflexible state that constrains managers from responding adaptively to changing conditions and, ultimately, from finding a sustainable direction for the future governance of the Tongass. As long as the dominant venues of stakeholder input in Tongass decision making are adversarial-i.e., through appeals and litigationthe institutional subsystem will remain "trapped" in the collapse $[\Omega]$ phase.
Likewise, the Tongass timber leases left a difficult legacy for the economic subsystem, in terms of the local capacity to profitably manufacture forest products. Because the lease contracts were linked with the pulp mills, when the mills closed and the leases were terminated, the industry lost its capacity to process the low-grade materials that comprise much of the Tongass timber base. Despite improving markets in recent years, local industry production has remained near historical lows, indicating that the industry has lost much of the flexibility that was apparent during the market downturns of the 1980s (Brackley et al. 2006). One explanation for this outcome is the decline of local mill infrastructure; in terms of technology and efficiency, most regional mills have remained largely unimproved since the 1980s (if not earlier). Industry analysts suggest that improvements in local mills are needed to compete in global markets (Crone 2004). Yet with a high degree of uncertainty that future timber sales will survive appeals and litigation (U.S. Forest Service 2004), any substantial investments in local mills is unlikely in the near term (Nie 2006). This uncertainty, in concert with structural changes in the regional industry, maintains the economic subsystem in a rigidity trap that will be difficult to escape.

Lastly, the yielding of Forest Service control over harvesting schedules to timber companies led to the "landscape-scale high grading" of the Tongass, in which lease holders targeted the most productive forests to maximize profits (Durbin 1999). Although precise data are not available, based on biophysical models and historical harvest maps, it is estimated that less than one-third of the most productive "big-tree" rainforests in the entire Tongass remain unharvested (C. Beier, unpublished data). Nearly all of these remaining big-tree forests are either protected by federal legislation (such as the ANILCA) or reserved from logging in the oldgrowth networks of the 1997 Forest Plan. As a result, the most productive stands in the current timber base of the Tongass are many decades from being harvestable, which further constrains opportunities for reorganization.

\section{Escaping the Legacy of Social Traps}

Recent developments suggest a potential pathway out of these rigidity traps and reorganization toward more sustainable governance of the Tongass. In 2000 , with the cooperation of a regional 
environmental advocacy coalition, forest managers began a "microsale" program that offers very small quantities of very high-grade timber, relative to historical sales. These offers involve up to 50000 board feet per sale, which may equate to as few as 10 individual trees; in contrast, standard clearcut harvest units typically range into several millions of board feet across hundreds of acres. With microsales, trees are harvested using selection logging and aerial yarding methods that have minimal ecological impact compared with the large clearcut harvests of the past five decades. Tongass microsales also meet local demand and provide opportunities for value-added manufacturing, and perhaps most importantly, all sales have involved competitive bidding and none have been challenged in court. Further advancements in cooperation and building trust among stakeholders are also evident. In 2006, the Tongass entered into its first-ever institutional partnership with an environmental organization-The Nature Conservancy of Alaska - to support community-based management of second-growth forests for improving wildlife habitat, future timber values, and several other ecosystem services. Both programs suggest an institutional change that may allow adaptation to new conditions while allowing forest managers to continue to produce economic benefits for local communities, in part through timber production. At the same time, globalization and changes in national and global values have altered the economic context (e.g., through expanded ecotourism; Colt et al. 2006) and provided new ways in which the Tongass can provide valuable ecosystem services to society.

\section{CONCLUSIONS AND BROADER IMPLICATIONS}

Governance of the Tongass National Forest began as a large-scale social experiment to bring manifest destiny into the 20th century. The vision was to spur regional development and solidify political influence over the resource-rich Alaskan territory that had been acquired by the U.S. only a few decades previously. The social goal was to create sustainable livelihoods for local residents and demonstrate the economic self-sufficiency needed to justify Alaskan statehood. Today, a century later, the emergence of large-scale forestry, agricultural, and hydroelectric projects in developing nations has a strikingly familiar tone, although now framed in a different paradigm. These governance systems are often centrally designed and funded to achieve political, social, and economic goals, and are implemented in ways that buffer against economic and political uncertainties so as to ensure success. Yet our case study of the Tongass, like many others (Gunderson et al. 1995), suggests this "commandand-control" approach is bound to failure (Holling and Meffe 1996). How can our application of the adaptive-cycle diagnostic to the Tongass case help guide a more adaptive and sustainable governance of resources to achieve broad societal goals?

Our case study warns against formation of a policy monopoly-of government funders, agency managers, and resource users - for rigidly buffering a governance system against change. This "iron triangle" (Kingdon 1995) made the Tongass efficient in producing timber and supporting local economic growth during its boom years, but became increasingly rigid and prevented adaptation to changing social preferences as well as shifting economic and ecological realities. This rigidity contributed to the rapid, catastrophic nature of system collapse and its persistent legacy in the region. Since collapse, remnants of this policy monopoly have continued to constrain institutional adaptive capacity - over a decade since closure of the last pulp mill in Alaska, most timber sales offered by Tongass managers are for pulp-grade timber (Beier 2007), few of which are ever harvested in the face of vigorous legal challenges. After decades of contentious debate among politicians, managers, and resource users, these actors have heretofore been reluctant to reach any consensus on alternative visions for the future of the Tongass.

The Tongass case also affirms that when agencies charged with management of common property resources yield too much authority to narrowly focused private interests, even in the pursuit of improving human well-being, the public welfare suffers in the long run (Ostrom 1990). Such rentseeking behavior has been a common symptom among large-scale forest governance systems around the world (Repetto and Gills 1998, Ross 2001). Our case study illustrates how boundaries can be distorted between the governance of a SES and the management of a specific resource, and how negative outcomes can emerge and persist, regardless of the initial purpose of managers and decision makers. In other words, when governance becomes too driven by a singular management emphasis that is rigidly organized, even the bestlaid plans will likely fail. 
Lastly, our case study suggests that efforts to resist social and ecological change will ultimately fail, and attempts to stabilize the system through rigidity will constrain future adaptive capacity. The Tongass system was designed to minimize SES change in response to external perturbations and constrain variability in every possible dimension: (1) political variability was minimized through a policy monopoly that established and safeguarded the long-term lease contracts and associated subsidies; (2) economic variability was buffered through subsidies and incentives designed to overcome local economic challenges and constrain the impact of global markets on local profitability; (3) ecological variability, specifically the structural heterogeneity of the future forest, was constrained through evenaged management practices; and (4) institutional variability, such as the growing emphasis on environmental research to understand impacts of management activities, was suppressed through "appropriation politics" and similar measures. In each of these subsystems, this rigidity has resulted in social traps that act in concert to inhibit the adaptive renewal of Tongass governance, and to some extent, the larger regional SES.

Overall, this legacy has interrupted the Tongass adaptive cycle because the system has been unable to reorganize for renewal in the new post-collapse context. We suggest this has occurred because the Tongass system emphasized the control of variability and prevented the gradual adaptation to changing social and economic conditions. An analogy between a democratic society and a forest ecosystem helps illustrate this point; in both, release and renewal-e.g., through regular elections or forest fires-need to occur regularly. Suppressing inherent variability prevents these dynamics (Holling et al. 2002b). In such cases, if the system is prevented from going through these cycles-for example, through policy monopoly or fire suppression practices-then when collapse does occur, it is typically catastrophic, with a difficult legacy that impedes renewal. In both cases, the aftermath suggests the difference between "healthy" and "pathological" dynamics of an adaptive cycle; when pathological, the system remains trapped in the collapse $[\Omega]$ phase far longer. For the Tongass, as of 2009, this prolonged collapse has lasted almost two decades.

Reorganization of the Tongass into a more sustainable system ultimately depends on reconciliation among local and national stakeholders, their advocates, and the agency that manages their interests for the common benefit. In a study of similar deadlock in forest governance in New Brunswick, Canada, Baskerville (1995) showed how abrupt changes in forest policy can foster such a reconciliation, and in turn, transformation of governance toward a sustainable balance of forest values. In Alaska, several promising trendsimproving market conditions, a growing emphasis on managing second-growth for future values, new partnerships with conservation organizations, and new political leadership at the state and national levels - suggest the critical opportunity for Tongass renewal is now.

Responses to this article can be read online at: http://www.ecologyandsociety.org/voll4/iss2/art5/responses/

\section{Acknowledgments:}

We are grateful to A. D. McGuire, J. A. Greenberg, G. P. Juday (at the University of Alaska-Fairbanks), and A. Brackley, L. Kruger, W. Kessler, and G. Robertson (at the U.S. Forest Service) for helpful discussions throughout this research. A. D. McGuire and J. A. Greenberg also assisted with preparation of an earlier version of this manuscript that appears in C. M. Beier's doctoral dissertation. Thanks also to several anonymous referees who provided comments to improve the manuscript. This work was funded by the Resilience and Adaptation Program (IGERT, NSF 0114423) at the University of AlaskaFairbanks, with in-kind support by the USDA Forest Service Pacific Northwest Research Station, Juneau Forestry Sciences Laboratory in Juneau, Alaska.

\section{LITERATURE CITED}

Allen, S. D., G. Robertson, and J. Schaefers. 1998. Economics in transition: an assessment of regional and community economic conditions and trends in southeast Alaska. General Technical Report PNW GTR 417. U.S. Department of Agriculture, Forest Service, Pacific Northwest Research Station. Portland, Oregon, USA.

Baskerville, G. L. 1995. The forestry problem: adaptive lurches of renewal. Pages 37-102 in L. H. Gunderson, C. S. Holling, and S. S. Light, editors. 
Barriers and bridges to the renewal of ecosystems and institutions. Columbia University Press, New York, New York, USA.

Baumgartner, F. R., and B. D. Jones. 1993. Agendas and instability in American politics. University of Chicago Press, Chicago, Illinois, USA.

Beier, C. M. 2007. Regional climate, federal land management, and the social-ecological resilience of southeastern Alaska. Dissertation, University of Alaska - Fairbanks, Fairbanks, Alaska, USA.

Beier, C. M. 2008. Influence of political opposition and compromise on conservation outcomes in the Tongass National Forest, Alaska. Conservation Biology 22(6):1485-1496.

Beier, C. M., T. M. Patterson, and F. S. Chapin, III. 2008. Ecosystem services and emergent vulnerability in managed ecosystems - a geospatial decision-support tool. Ecosystems 11(6):923-938.

Bliss, J. 2000. Public perceptions of clearcutting. Journal of Forestry 98(12):4-9.

Brackley, A. M., D. J. Parrent, and T. J. Rojas. 2006. Estimating sawmill processing capacity for Tongass timber: 2003 and 2004 update. Research Note PNW-RN-533. U.S. Department of Agriculture, Forest Service, Pacific Northwest Research Station, Portland, Oregon, USA.

Cahn, R. 1982. The fight to save wild Alaska. National Audubon Society, Washington, D.C., USA.

Carpenter, S. R., and W.A. Brock. 2008. Adaptive capacity and traps. Ecology and Society 13(2): 40. [online] URL: http://www.ecologyandsociety.org/voll3/ iss $2 / \operatorname{art} 40 /$.

Colt, S., D. Dugan, and G. Fay. 2006. The regional economy of southeast Alaska-final report. Institute of Social and Economic Research, University of Alaska - Anchorage, Anchorage, Alaska, USA. [online] URL: http://iser.uaa.alaska.e du/Publications/SoutheastEconomyOverviewfinal4. pdf.

Costanza, R. 1987. Social traps and environmental policy. BioScience 37:407-412.
Crone, L. K. 2004. Southeast Alaska economics: a resource-abundant region competing in a global marketplace. Landscape and Urban Planning 72:215-232.

Durbin, K. 1999. Tongass: pulp politics and the fight for the Alaska rain forest. Oregon State University Press, Corvallis, Oregon, USA.

Francis, G. R., and H. A. Reiger. 1995. Barriers and bridges to the restoration of the Great Lakes basin ecosystem. Pages 239-291 in L. H. Gunderson, C. S. Holling, and S. S. Light, editors. Barriers and bridges to the renewal of ecosystems and institutions. Columbia University Press, New York, New York, USA.

Gunderson, L. H., C. S. Holling, and S. S. Light, editors. 1995. Barriers and bridges to the renewal of ecosystems and institutions. Columbia University Press, New York, New York, USA.

Hanley, T.A., W. P.Smith, and S. M. Gende. 2005. Maintaining wildlife habitat in southeastern Alaska: implications of new knowledge for forest management and research. Landscape and Urban Planning 72:113-133.

Holling, C. S., and L. H. Gunderson. 2002. Resilience and adaptive cycles. Pages 25-62 in L. H. Gunderson and C. S. Holling, editors. Panarchy: understanding transformations in human and natural systems. Island Press, Washington, D.C., USA.

Holling, C. S., L. H. Gunderson, and D. Ludwig. 2002a. In quest of a theory of adaptive change. Pages 3-22 in L. H. Gunderson and C. S. Holling, editors. Panarchy: understanding transformations in human and natural systems. Island Press, Washington, D.C., USA.

Holling C. S., L. H. Gunderson, and G. Peterson. 2002b. Sustainability and panarchies. Pages 63-102 in L. H. Gunderson and C. S. Holling, editors. Panarchy: understanding transformations in human and natural systems. Island Press, Washington, D.C., USA.

Holling, C. S., and G. K. Meffe. 1996. Command and control and the pathology of natural resource management. Conservation Biology 10:328-337.

Kingdon, J. W. 1995. Agendas, alternatives and 
public policies. Addison-Wesley, New York, New York, USA.

Lee, K. N. 1995. Deliberately seeking sustainability in the Columbia River Basin. Pages 214-238 in L. H. Gunderson, C. S. Holling, and S. S. Light, editors. Barriers and bridges to the renewal of ecosystems and institutions. Columbia University Press, New York, New York, USA.

LeMaster, D. 1984. Decade of change: the remaking offorest service statutory authority during the 1970s. Greenwood Press, Westport, Connecticut, USA.

Light, S. S., L. H. Gunderson, and C. S. Holling. 1995. The Everglades: evolution of management in a turbulent ecosystem. Pages 103-168 in L. H. Gunderson, C. S. Holling, and S. S. Light, editors. Barriers and bridges to the renewal of ecosystems and institutions. Columbia University Press, New York, New York, USA.

Malmsheimer, R. W., D. Keele, and D. W. Floyd. 2004. National forest litigation in the U.S. Courts of Appeals. Journal of Forestry 102(2):20-25.

Morse, K. S. 2000. Responding to the market demand for Tongass timber: using adaptive management to implement Sec. 101 of the Tongass Timber Reform Act. R10-MB-413. U.S. Department of Agriculture, Forest Service, Alaska Region, Juneau, Alaska, USA.

Nelson, D. 2004. Northern landscapes: the struggle for wilderness Alaska. RFF Press, Washington, D. C., USA.

Nie, M. 2006. Governing the Tongass: national forest conflict and decision-making. Environmental Law 36:385-480.

Ostrom, E. 1990. Governing the commons: the evolution of institutions for collective action. Cambridge University Press, Cambridge, UK.

Ostrom, E. 2007. A diagnostic approach for going beyond panaceas. Proceedings of the National Academies of Science 104:15181-15187.

Pauly, D., J. Alder, A. Bakun, S. Heileman, K.-H. Kock, P. Mace, W. Perrin, K. Stergiou, U. R. Sumaila, M. Vierros, K. Freire, and Y. Sadovy. 2005. Marine fisheries systems. Pages 477-511 in
Millennium Ecosystem Assessment. Ecosystems and human well-being: current state and trends. Island Press, Washington, D.C., USA.

Rakestraw, L. 1989. A History of the United States Forest Service in Alaska. U.S. Department of Agriculture, Forest Service, R10-ER-5.

Rasband, J., J. Salzman, and M. Squillace. 2004. Natural resources law and policy. Foundation Press, New York, New York, USA.

Repetto. R. C. 1988. Subsidized timber sales from national forest lands in the United States. Pages 353-379 in R. Repetto and M. Gills, editors. Public policies and the misuse of forest resources. Cambridge University Press, London, UK.

Repetto, R., and M. Gills, editors. 1988. Public policies and the misuse of forest resources. Cambridge University Press, London, UK.

Ross, M. L. 2001. Timber booms and institutional breakdown in southeast Asia. Cambridge University Press, Cambridge, UK.

Soderberg, K. A., and J. DuRette. 1988. People of the Tongass-Alaska forestry under attack. Free Enterprise Press, Bellevue, Washington, USA.

Steen, H. K., editor. 2004. Jack Ward Thomas: the journals of a forest service chief. University of Washington Press, Seattle, Washington, USA.

Taylor, R. F. 1935. Available nitrogen as a factor influencing the occurrence of Sitka spruce and western hemlock seedlings in the forests of southeastern Alaska. Ecology 16(4):580-602

Trosper, R. L. 2003. Policy transformations in the US forest sector, 1970-2000: implications for sustainable use and resilience. Pages 328-351 in F. Berkes, J. Colding, and C. Folke, editors. Navigating social-ecological systems: building resilience for complexity and change. Cambridge University Press, Cambridge, UK.

True, J. L., B. D. Jones, and F. R. Baumgartner. 1999. Punctuated-equilibrium theory: explaining stability and change in American policymaking. Pages 97-116 in P. Sabatier, editor. Theories of the policy process. Westview Press, Chicago, Illinois, USA. 
U.S. Department of Agriculture (USDA) Forest Service. 2004. Questions and answers: Tongass National Forest. Press release, 12 Febrary 2004. U. S. Department of Agriculture, Forest Service, Alaska Region, Tongass National Forest, Ketchikan, Alaska, USA.

Walker, B., C. S. Holling, S. R. Carpenter, and A. Kinzig. 2004. Resilience, adaptability, and transformability in social-ecological systems. Ecology and Society 9(2): 5. [online] URL: http://w ww.ecologyandsociety.org/vol9/iss2/art5.

Whitney, D. 1996. Tongass plant to cost $\$ 110$ million: taxpayers will pay compensation for timber job losses in southeast Alaska. Anchorage Daily News, 12 May 1996, section C-1.

Wilkinson, C. F. 1997. The National Forest Management Act: the twenty years behind, the twenty years ahead. University of Colorado Law Review 68:659-665. 
Appendix 1. A timeline of key events in Tongass governance and forest management (1908-2008), divided into the four phases of the adaptive cycle: organization, growth, conservation and collapse.

Please click here to download file 'appendix1.pdf'. 
Appendix 2. Principal drivers and dynamics of change in the economic, political and institutional subsystems of the Tongass system from 1908-2008, divided into the four phases of the adaptive cycle.

Please click here to download file 'appendix2.pdf'. 
APPENDIX 3. Federal legislation and a keystone judicial decision influencing Tongass governance

Multiple Use Sustained Yield Act of 1960 (MUSYA) - formally articulated the mission of USFS to include managing for "outdoor recreation, range, timber, watershed and wildlife and fish purposes." Yet due to vague language, the mandate of MUSYA has been subject to diverse interpretation and prolonged debate. In the Tongass, for example, MUSYA has been invoked to justify the offering of 8.7 billion board-feet of old-growth timber to single purchaser; and three decades later, the potential designation of 58 million acres of roadless areas as federally-protected wilderness reserves (Nie 2006). This ambiguous mandate provided the basis for legal challenges to forest planning actions (Rasband et al. 2004), and MUSYA became a major challenge for an agency focused on the dominant use of National Forests for timber (Clary 1986).

Wilderness Act of 1964 - required all roadless public lands to be evaluated for potential wilderness designation. The Wilderness Act added another non-timber land use to the multiple-use mandate of the USFS.

Administrative Procedures Act of 1966 (APA) - enacted broad reforms on the bureaucratic procedures of all federal agencies. The legislation required greater transparency in the agency planning process and created the basis for agency decisions to be appealed by public stakeholders and interest groups. As a result, the appeals process became a primary venue of conflict resolution and communication between public groups and the USFS (Nie 2006).

National Environmental Policy Act of 1969 (NEPA) - amended in 1971 and 1973, required all management actions complete a scientific review process to evaluate environmental impacts. Under NEPA, these Environmental Impact Statements (EIS) and Environmental Assessments (EA) have become fertile ground for legal challenges. Since NEPA, more environmental lawsuits have been based on EIS requirements than any other federal statute (Rasband et al. 2004). In the years immediately following NEPA, federal judges typically deferred to the authority and expertise of the USFS. As the prevalence of NEPA-based appeals and litigation grew during the 1970s, this tendency gradually reversed as environmentalists found more favorable venues in the federal judicial system (LeMaster 1984; Nie 2006). The adequacy and accuracy of the science used in the EIS process was often the basis for legal challenges, especially with respect to the practice of clearcutting in National Forests (Clary 1986). In 1972, the U.S. Congress held extensive hearings on clear-cutting, due to growing public opinion opposing the practice (Bliss 2000).

Endangered Species Act of 1973 (ESA) - beset the USFS with additional environmental regulations and created a new venue for environmental litigation on the grounds of protecting biota affected by forest management practices. In conjunction with NEPA, ESA requirements to protect threatened and endangered species greatly complicated timber operations on U.S. National Forests (LeMaster 1984).

Freedom of Information Act of 1974 (FOIA) - made all institutional records publicly available. FOIA opened the planning and decision-making process to greater public and judicial scrutiny.

Sierra Club v Hardin - the first successful legal challenge to a Tongass timber sale, the lawsuit was initially filed in 1965, prior to the passage of NEPA and APA. While the initial ruling was in favor of the USFS, in subsequent proceedings, the plaintiffs used language from MUSYA, and later from NEPA, to delay and eventually block a large timber sale to the US Plywood Champion Company. The plaintiffs included local stakeholders who challenged the construction of a pulp mill in Echo Cove, north of Juneau. Because construction of the mill (as in Ketchikan and Sitka) was requisite for the lease contract, the several years of litigation and local opposition (although it reflected a minority) led to withdrawal of the sale in 1971. Sierra Club v Hardin was among the initial applications of NEPA to block a major federal agency decision, and the first time it was used to block a federal timber sale (Rakestraw 1989; Nie 2006). 